\title{
Technical note: A vacuum-assisted approach for biopsying the mammary glands of various species
}

\author{
M. K. VanKlompenberg, H. F. McMicking, and R. C. Hovey ${ }^{1}$ \\ Department of Animal Science, One Shields Avenue, University of California, Davis 95616
}

\begin{abstract}
Biopsy of the mammary glands is a technique used in both research and clinical diagnosis. A vacuum-assisted approach that enables the collection of tissue from the mammary glands of various species is described, along with methods for biopsying cows and pigs. The procedure involves tissue penetration via blunt dissection with a sharpened trocar. Tissue cores are excised and collected via the vacuum-assisted handpiece followed by a saline lavage and wound closure. This approach yields tissue cores of approximately $100 \mathrm{mg}$, is well suited for use in various species, and affords the potential to reduce postoperative complications.
\end{abstract}

Key words: biopsy, mammary gland, udder

\section{Technical Note}

Biopsy of tissue from the mammary glands permits the study of processes underlying growth and lactation (Farr et al., 1996) as well as for the diagnosis of breast cancer in humans (Wilson and Kavia, 2009). From a research perspective, the advantages of such an approach include the opportunity to repeatedly sample the same animal while removing the need for major surgery or euthanasia.

Methods for biopsying the mammary glands of livestock have undergone notable refinement from the initial approach of surgical lumpectomy (Knight and Peaker, 1984). Two methods are commonly reported for use in large animals. A drill-operated coring instrument for use in cows collects a core that is approximately 0.75 to $1.0 \mathrm{~g}$ (Farr et al., 1996), but this approach has several limitations. The dimensions of the instrument (internal diameter of $4.5 \mathrm{~mm}$, length of $85 \mathrm{~mm}$ ) preclude its use in species with smaller mammary glands, such as swine, goats, and primates. This drill-operated instrument excises a core to the externus that may exacerbate external bleeding. An alternative approach is a core needle biopsy (such as the Bard biopsy gun

Received May 23, 2011

Accepted September 16, 2011.

${ }^{1}$ Corresponding author: rchovey@ucdavis.edu and needle) that acquires tissue from the mammary glands of cows and goats (Puvogel et al., 2005; Ollier et al., 2009). This method requires a smaller incision and reduces bleeding, but yields smaller tissue cores of 20 to $25 \mathrm{mg}$.

Biopsies of the human breast are typically performed in the clinical setting for cancer diagnosis. Initial approaches used fine-needle aspiration that provided sufficient tissue for cytological analysis (Wilson and Kavia, 2009). The yield of tissue was inadequate for histological analysis, which resulted in some cancers going undiagnosed. Development of a large-core biopsy technique allowed for both histological and cytological analyses; the most commonly used technique is vacuum-assisted mammotomy that can be combined with $\mathrm{X}$-ray, ultrasound, and magnetic-resonance guidance.

The use of the Hologic ATEC Breast Biopsy and Excision System (the Pearl unit; Hologic Inc., Bedford, MA) that includes a biopsy handpiece connected to a vacuum pump console $(63 \times 93 \times 53 \mathrm{~cm}$ generating a vacuum pressure of $710 \mathrm{~mm} \mathrm{Hg}$ ) is outlined. Handpieces for the Pearl unit come in several combinations of cutting cannulas that comprise different needle gauges (9 or 12 gauge), lengths $(9,12$, or $14 \mathrm{~cm})$, and aperture lengths (12 or $20 \mathrm{~mm}$ ). The outer cannula needle has a trocar tip for blunt penetration and an aperture for sampling (Figure 1). A saline line is attached to the handpiece along with 2 pneumatic motor lines and an aspiration line that connects to the rear of the handpiece via the tissue filter holder. During each biopsy, tissue is collected into the aperture after which the sharpened inner cannula cuts the tissue core that is then aspirated into the tissue collection filter. The cutting cannula is activated via a foot pedal. After the tissue core is collected, a saline lavage or aspiration of the excision site can be performed.

The objective was to determine a method that would permit serial biopsy of the mammary glands in several animal species. Methods for biopsying the mammary glands of cows and pigs are reported. All procedures were approved by the University of California, Davis Institutional Animal Care and Use Committee.

Biopsies were performed on lactating cows and heifers $(\mathrm{n}=12)$, some of which $(\mathrm{n}=9)$ were hormonally in- 


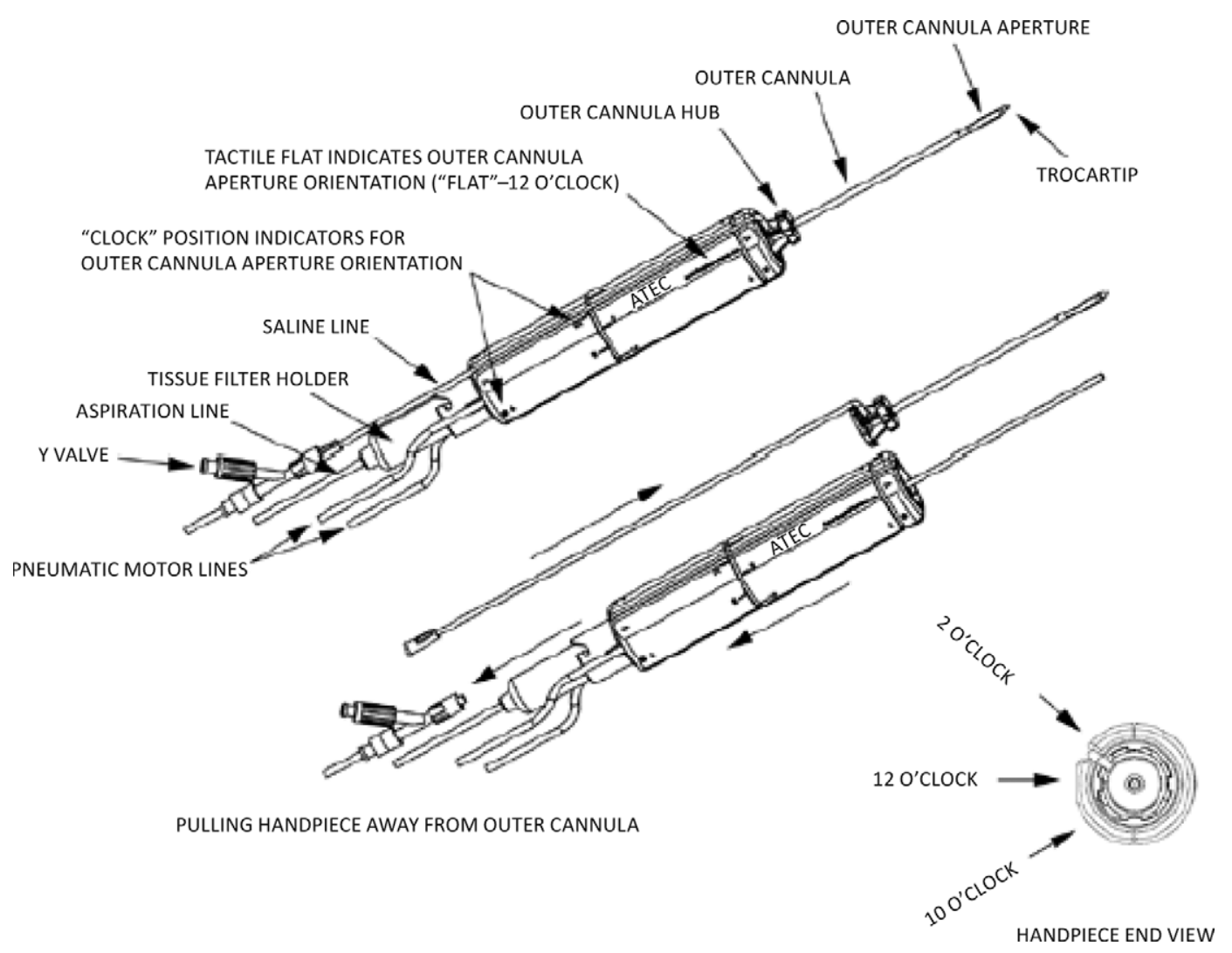

Figure 1. Schematic of the Hologic ATEC Biopsy Console Handpiece (Hologic Inc., Bedford, MA) showing the removable outer cannula in side and end views. Photo courtesy of Hologic Inc. (C) 2011. All rights reserved.

duced to lactate (Smith and Schanbacher, 1973). Cows were milked before the procedure and restrained in a headlock or squeeze chute that allowed them to remain standing for the entire procedure. The handpiece had a 9-gauge, $12-\mathrm{cm}$ needle having either a 12 - or $20-\mathrm{mm}$ aperture. Animals were administered AnaSed (xylazine hydrochloride, Lloyd Laboratories, Shenandoah, IA; 40 $\mu \mathrm{g} / \mathrm{kg}$, i.v.), and the surgical site was shaved and prepared aseptically followed by a field block of lidocaine hydrochloride (Hospira Inc., Lake Forest, IL; $3 \mathrm{~mL}, 20$ $\mathrm{mg} / \mathrm{mL}$, s.c.). A $5-\mathrm{mm}$ incision was made through the skin and connective tissue approximately half-way up the rear udder quarter. After blunt penetration of the underlying parenchyma with the biopsy probe, 2 tissue cores were excised. A saline lavage was performed until the aspirate in the clear tissue filter holder at the base of the handpiece clarified, which was usually after approximately 25 to $75 \mathrm{~mL}$ of saline The incision site was closed with surgical staples (Appose ULC 35, United States Surgical, Norwalk, CT) followed by topical application of betadine ointment. The entire procedure took approximately $30 \mathrm{~min}$. The biopsied quarter was hand stripped approximately $1 \mathrm{~h}$ postsurgery and then twice daily after normal machine milking until no signs of blood or blood clots were visible in the milk, which was no more than $7 \mathrm{~d}$ postbiopsy. The incision site was monitored daily until staples were removed $7 \mathrm{~d}$ later. Temperature was monitored twice daily for $1 \mathrm{wk}$ postbiopsy, and did not deviate by more than $1.8^{\circ} \mathrm{C}$ from the initial presurgery temperature at any point $(\mathrm{n}=4$ cows $)$. Some cows $(\mathrm{n}=3)$ were prophylatically treated with Excenel RTU (ceftiofur hydrochloride, Pfizer Animal Health, Kalamazoo, MI; $30 \mathrm{~mL}, 50 \mathrm{mg} /$ $\mathrm{mL}$, s.c.). The mass of tissue cores collected from the induced lactation animals was not recorded. Samples collected from a mid-lactation Jersey cow using the 12$\mathrm{mm}$ aperture totaled $135 \mathrm{mg}$ for 2 cores. All samples were weighed to within $0.1 \mathrm{mg}$ using a Mettler Toledo XS64 analytical balance (Mettler Toledo, Columbus, $\mathrm{OH})$.

This biopsy technique was used to serially sample the mammary glands of first-parity gilts $(\mathrm{n}=9)$ during late gestation and lactation. The procedure was the same as in cows with the following modifications. Pigs were restrained using a snare, and the gland was field blocked with lidocaine hydrochloride (s.c., $3 \mathrm{~mL}, 20 \mathrm{mg} / \mathrm{mL}$ ). All biopsies were performed using a 9-gauge, $12-\mathrm{cm}$ probe with a $12-\mathrm{mm}$ aperture. VetBond adhesive (3M 
Table 1. Tissue core mass $( \pm \mathrm{SE})$ obtained using the 12-mm-aperture handpiece to sample the mammary glands of pregnant and lactating first-parity gilts

\begin{tabular}{llcccr}
\hline $\begin{array}{l}\text { Day of } \\
\text { study }\end{array}$ & Stage & $\mathrm{n}$ & $\begin{array}{c}\text { Mass } \\
(\mathrm{mg})\end{array}$ & $\begin{array}{c}\text { SE } \\
(\mathrm{mg})\end{array}$ & \multicolumn{1}{c}{$\begin{array}{c}\text { CV } \\
(\%)\end{array}$} \\
\hline 90 & Pregnant & 7 & 97.1 & 6.7 & 18.3 \\
100 & Pregnant & 4 & 82.1 & 2.3 & 5.7 \\
110 & Pregnant & 9 & 79.6 & 3.9 & 16.3 \\
2 & Lactating & 7 & 80.4 & 3.7 & 13.6 \\
21 & Lactating & 8 & 94.0 & 8.3 & 26.4 \\
\hline
\end{tabular}

Company, St. Paul, MN) was used to close the incision site in nonlactating animals, whereas surgical staples were used for lactating animals. The entire procedure lasted approximately $10 \mathrm{~min}$. The incision site was monitored twice daily for $1 \mathrm{wk}$. Staples were removed 4 d postbiopsy. The average mass of each tissue core from the pregnant and lactating gilts ranged from 79 to 97 mg (Table 1).

Tissue collected from cows and pigs was analyzed histologically and for gene expression. Briefly, biopsy cores were fixed, embedded in paraffin, and sectioned before staining with hemotoxylin and eosin. Histological analysis of mammary tissue excised from an induced lactation heifer confirmed an abundance of epithelium (Figure 2A). Integrity of RNA and gene expression were analyzed in tissue obtained from 2 late-gestation (d 110) gilts. A core of tissue was flash frozen before extraction of RNA, reverse transcription, and PCR for prolactin receptor $(p P R L R$, forward: AAGGAAACATTCACCTGCTG, reverse: AATCCTTTTATTTTTGGCCC), $\beta$-casein ( $p C A S \mathscr{Q}$, forward: AGAATGAACGCCAGAATAAAATCC, reverse: TGGTTGAGGCACAGGGTAGAA), and whey acidic protein ( $p W A P$, forward: ACCCCTGCGTAATCTCCTGCGTCAAC, reverse: ACACTGGTCGTCCCTGGAGCACTCATTT). Figure 2B depicts the integrity of ribosomal RNA subunits revealed by formaldehyde-agarose gel electrophoresis. Analysis of gene expression for $p P R L R, p C A S 2$, and $p W A P$ confirmed detectable mRNA expression for all 3 genes.

To further compare tissue yield using the vacuumassisted approach (12- vs. 20-mm aperture) and the drill-operated tool (Farr et al., 1996), each instrument was used to collect 10 cores of tissue from the udder of a necropsied cow having unknown history. The 12-mmaperture needle yielded cores of $79.1 \pm 3.9 \mathrm{mg}$, whereas the 20-mm-aperture needle yielded cores of $153.9 \pm$ $5.4 \mathrm{mg}$ (Table 2). The drill-operated tool yielded cores averaging $586.7 \pm 56.9 \mathrm{mg}$. The average mass of tissue cores collected using the vacuum-assisted method had a smaller coefficient of variation regardless of aperture size compared with the drill-operated tool (Table 2).
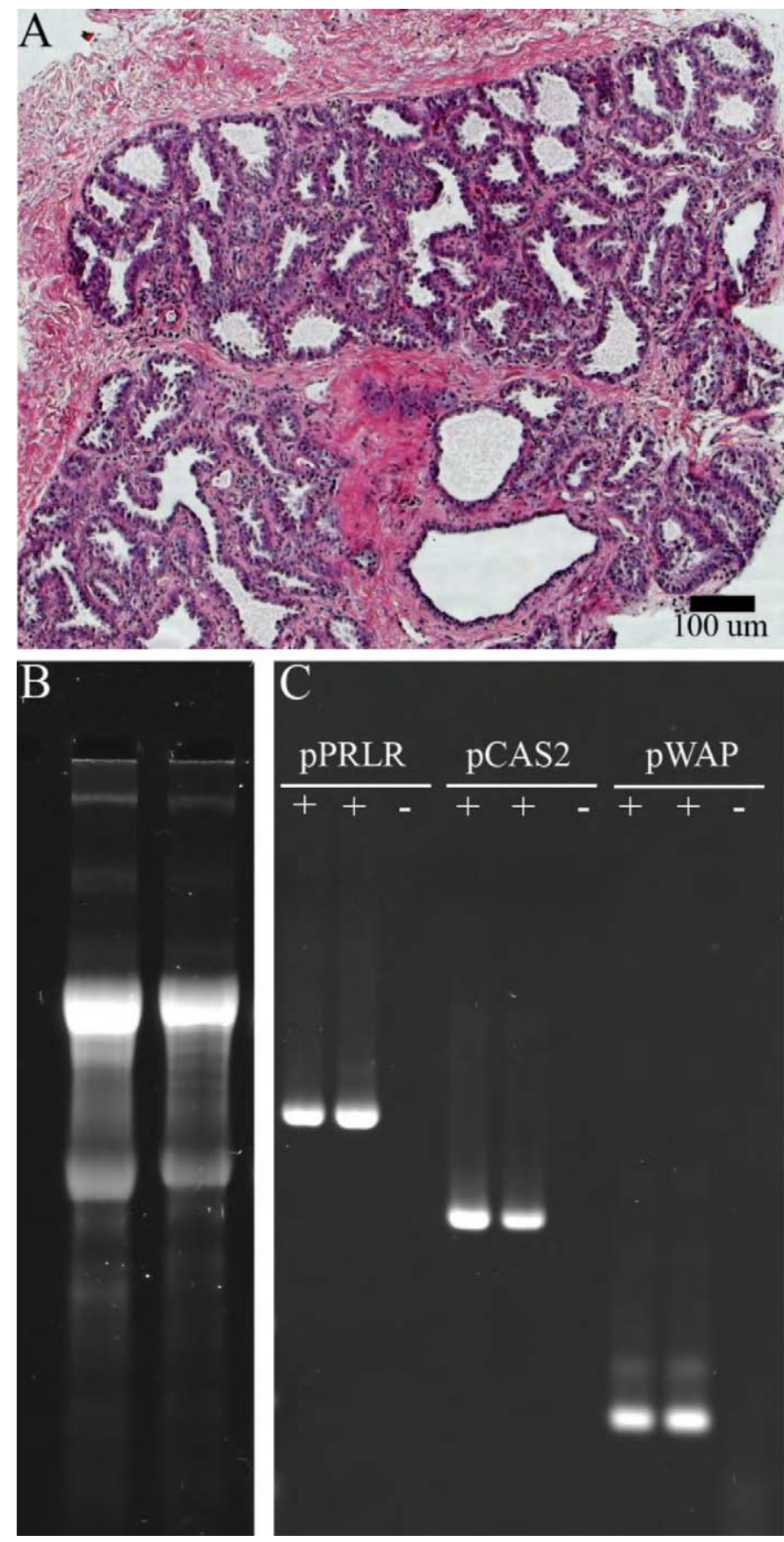

Figure 2. Analysis of mammary tissue obtained by vacuumassisted biopsy. (A) Section of mammary tissue, from an inducedlactation heifer, stained with hemotoxylin and eosin and depicting an abundance of epithelium. (B) Integrity of ethidium bromide-stained ribosomal RNA subunits revealed by formaldehyde-agarose gel electrophoresis. Total RNA was extracted from biopsy samples collected from the mammary glands of 2 pregnant gilts (d 110 of pregnancy). (C) Analysis of mRNA expression for porcine prolactin receptor $(p P R L R)$, $\beta$-casein $(p C A S 2)$, and whey acidic protein $(p W A P)$ in tissue from 2 gilts biopsied at d 110 of pregnancy. The PCR reactions for the 2 samples $(+)$ and the negative control reaction $(-)$ for each gene were analyzed by ethidium bromide-stained agarose gel electrophoresis. Color version available in the online PDF. 
Table 2. Mass $( \pm \mathrm{SE})$ of tissue cores collected from a cow udder using 2 different handpiece aperture sizes or the drill-operated coring instrument $(\mathrm{n}=10$ cores per tool)

\begin{tabular}{lccc}
\hline Tool & $\begin{array}{c}\text { Mass } \\
(\mathrm{mg})\end{array}$ & $\begin{array}{c}\mathrm{SE} \\
(\mathrm{mg})\end{array}$ & $\begin{array}{c}\mathrm{CV} \\
(\%)\end{array}$ \\
\hline 12-mm aperture & 79.1 & 3.9 & 15.7 \\
20-mm aperture & 153.9 & 5.4 & 11.0 \\
Drill-operated tool & 586.7 & 56.9 & 30.7 \\
\hline
\end{tabular}

The vacuum-assisted approach has several benefits for biopsying the mammary glands of species such as cattle and pigs. First, blunt penetration (compared with excising a core to the externus) likely decreases the amount of external bleeding and appeared to improve healing and wound closure. Second, the vacuumassisted approach allowed for a saline lavage within the gland at the biopsy site, with or without epinephrine to promote vasoconstriction. Third, the tissue sample size was more appropriate for species with smaller mammary glands such as the monkey, pig, and goat. Compared with the method described by Farr et al. (1996), one disadvantage of the vacuum-assisted method is that it yields smaller amounts of tissue. However, multiple cores can be collected from the same incision site by rotating the handpiece. One major consideration in evaluating the Hologic ATEC Breast Biopsy Excision System is the higher costs of purchase and consumables compared with other methods. Although the handpieces are marketed for single use in human medicine, they were routinely gas-sterilized and reused, in compliance with IACUC guidelines.

In conclusion, vacuum-assisted biopsy of the mammary glands can be performed in several animal species using the Hologic ATEC Breast Biopsy Excision System. Blunt penetration and saline lavage likely help improve wound healing. The smaller tissue core size is offset by the ability to collect multiple cores from the same site.

\section{ACKNOWLEDGMENTS}

This work was supported by a National Science Foundation Graduate Research Fellowship under Grant No. DGE-0707429, Grant \# BC098018 from the Department of Defense Breast Cancer Research Program, and National Research Initiative Competitive Grant \# 2008-35206-18895 from the USDA National Institute of Food and Agriculture. We thank the staff at the University of California, Davis Swine, Dairy, and Meat Facilities for their assistance.

\section{REFERENCES}

Farr, V. C., K. Stelwagen, L. R. Cate, A. J. Molenaar, T. B. McFadden, and S. R. Davis. 1996. An improved method for the routine biopsy of bovine mammary tissue. J. Dairy Sci. 79:543-549.

Knight, C. H., and M. Peaker. 1984. Mammary development and regression during lactation in goats in relation to milk secretion. Q. J. Exp. Physiol. 69:331-338.

Ollier, S., C. Leroux, A. de la Foye, L. Bernard, J. Rouel, and Y. Chilliard. 2009. Whole intact rapeseeds or sunflower oil in highforage or high-concentrate diets affects milk yield, milk composition, and mammary gene expression profile in goats. J. Dairy Sci. 92:5544-5560.

Puvogel, G., C. R. Baumrucker, H. Sauerwein, R. Ruhl, E. Ontsouka, H. M. Hammon, and J. W. Blum. 2005. Effects of an enhanced vitamin A intake during the dry period on retinoids, lactoferrin, IGF system, mammary gland epithelial cell apoptosis, and subsequent lactation in dairy cows. J. Dairy Sci. 88:1785-1800.

Smith, K. L., and F. L. Schanbacher. 1973. Hormone-induced lactation in the bovine. I. Lactational performance following injections of 17ß-estradiol and progesterone. J. Dairy Sci. 56:738-743.

Wilson, R., and S. Kavia. 2009. Comparison of large-core vacuum-assisted breast biopsy and excision systems. Recent Results Cancer Res. 173:23-41. 